
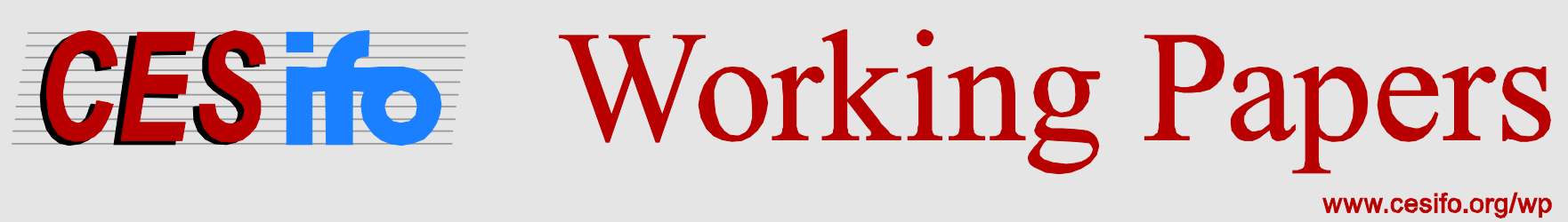

\title{
Debt Brakes in the German States: Governments' Rhetoric and Actions
}

\author{
Niklas Potrafke \\ Marina Riem \\ Christoph Schinke
}

CESIFO WORKING PAPER NO. 5696

CATEgory 2: PUBliC CHOICE

JANUARY 2016

An electronic version of the paper may be downloaded

- from the SSRN website:

- from the RePEc website:

- from the CESifo website: www.SSRN.com

Www.RePEc.org

www.CESifo-group.org/wp

ISSN 2364-1428

CESifo 


\title{
Debt Brakes in the German States: Governments’ Rhetoric and Actions
}

\begin{abstract}
In 2009 a new law on German debt brakes was passed: state governments are not allowed to run structural deficits after 2020. Consolidation strategies initiated today influence if a state can comply with the debt brake in 2020. We describe to what extent government ideology predicts if state governments consolidate budgets and which fiscal adjustment path they choose. Attitudes towards budget consolidation, as expressed by politicians' words in the public debate, differed among parties. Anecdotal evidence and descriptive statistics indicate that leftwing governments ran on average higher structural deficits than rightwing governments between 2010 and 2014 . Primary deficits, however, hardly differed under leftwing and rightwing governments. Revenues of federal taxes were much higher than expected and facilitated budget consolidation. Leftwing governments did not need to run deficits to design generous budgets. It is conceivable that parties confirmed their identity by using expressive rhetoric, but responded to shifts in public opinion after the financial crisis and pursued more sustainable fiscal policies when in office.
\end{abstract}

JEL-codes: D720, H600, H720.

Keywords: government ideology, public debt, debt brake, balanced-budget rule, constitution, expressive rhetoric.

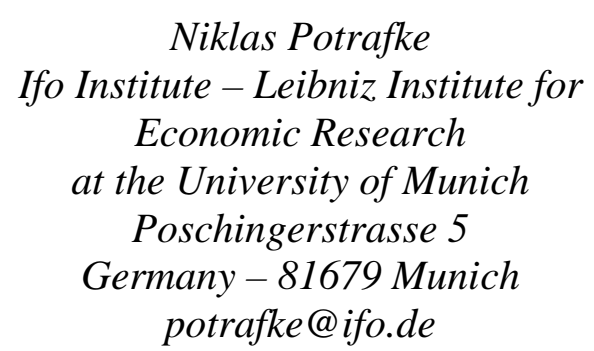

Marina Riem

Ifo Institute - Leibniz Institute for

Economic Research

at the University of Munich

Poschingerstrasse 5

Germany-81679 Munich

riem@ifo.de
Christoph Schinke

Ifo Institute - Leibniz Institute for

Economic Research

at the University of Munich

Poschingerstrasse 5

Germany - 81679 Munich

schinke@ifo.de

January 8, 2016

This paper has been accepted for publication in the German Economic Review. 


\section{Introduction}

Since the financial crisis 2008/2009, experts have stepped up efforts in discussing whether governments pursue sustainable fiscal policies (e.g. Alesina et al., 2015). In the course of demographic change, sustainable fiscal policies are an important case in point for industrialized societies. An issue is whether constitutional restrictions are needed to constrain excessive debt. Balanced-budget rules have been used by most US states, Spanish regions, and Swiss Cantons. In Germany, a balanced-budget rule, the 'debt brake', was included in the federal constitution in 2009. The new rules restrict the structural deficit of the federal government to a maximum of $0.35 \%$ of GDP from 2016 on. The German states are not allowed to run any structural deficit from 2020 onwards. The states, however, decide on the fiscal adjustment path until 2020. After 2019 the financial ties between the federal government and the states have to be reorganized. The debt brake is also an important issue in the negotiations between states regarding the fiscal equalization system after 2019. ${ }^{2}$ Both the debt brake and the fiscal equalization system influence state budgets. In 2014, there were almost 9 billion Euros horizontal transfers between the states. The fiscal equalization system provides incentives for states to incur debt instead of generating revenues which would get redistributed. When the debt brake is in full force and forbids deficit financed spending, highly indebted states may demand higher fiscal transfers to comply with the debt brake.

Many studies investigate how government ideology influences public expenditures and borrowing. The partisan theories predict that leftwing governments increase size and scope of government more than rightwing governments. Only few studies examine

\footnotetext{
${ }^{2}$ On fiscal transfers and fiscal sustainability in the German states see Potrafke and Reischmann (2015).
} 
whether leftwing and rightwing governments pursue different strategies to consolidate budgets.

The German federal government consisting of the conservative Christian Democratic Union (CDU/CSU) and the leftwing Social Democratic Party (SPD) initiated to introduce the debt brake. When the German lower house (Bundestag) decided to introduce the debt brake in May 2009, 19 out of 220 members of Parliament (MPs) of the SPD voted against introducing the debt brake (and against the party line), compared to just one out of 216 MPs of the CDU/CSU. In six German states, rightwing governments implemented debt brakes at the state level (Bavaria, Hesse, Lower Saxony, Saxony, Schleswig-Holstein, and Thuringia), while only three leftwing governments did so (Baden-Wuerttemberg, Hamburg, and Rhineland-Palatinate). ${ }^{3}$ Newspaper coverage also suggests that rightwing governments were more active in budget consolidation than leftwing governments. For example, the Frankfurter Allgemeine Zeitung wrote on June 22, 2014 that "Social Democrats do not want to save".

We describe to what extent government ideology predicts how state governments consolidate budgets in the German states. During the financial crisis 2008/2009 public debt in European countries drastically increased. In Germany the debt-to-GDP ratio increased from 74.5\% in 2009 to 82.5\% in 2010 (Monthly Report of the Federal Ministry of Finance, March 2013). Against the background of high deficit levels in 2010, the federal and state governments need to consolidate their budgets. German states decide on how to comply with the debt brake requirements. We examine which states included new fiscal rules in their legislation and whether government ideology influenced defi-

\footnotetext{
${ }^{3}$ As a leftwing government we consider SPD or SPD/Greens. A mixed coalition government is between $\mathrm{SPD}$ and $\mathrm{CDU} / \mathrm{CSU}$, CDU and Greens or CDU/FDP/Greens. A rightwing government is CDU/CSU or CDU/CSU/FDP.
} 
cits. We asked senior officials in the state ministries of finance which consolidation strategies state governments pursued.

Anecdotal evidence corroborates that political parties in the public debate differ considerably in their attitudes towards fiscal consolidation strategies. Descriptive statistics indicate that leftwing governments ran on average higher structural deficits than rightwing governments between 2010 and 2014. The average primary balance, however, did not differ significantly between rightwing and leftwing governments. In 2014, at the end of the observation period, all states ran primary surpluses. Revenues of federal taxes were much higher than expected. Leftwing governments did not need to run deficits to design generous budgets. Parties differed in their use of individual policy measures to consolidate budgets.

\section{Public Debt \& Government Ideology}

The partisan theories describe that leftwing governments appeal more to wage earners and promote expansionary fiscal and monetary policies (Hibbs, 1977; Alesina, 1987). ${ }^{4}$ With tax revenues being constant, leftwing governments are therefore expected to run deficits to finance high expenditures. ${ }^{5}$ Rightwing governments appeal more to capital owners, are more concerned with reducing inflation and run lower deficits. ${ }^{6}$

Strategic borrowing may also explain why government ideology influences deficits. If governments face the threat of being replaced by the opposition after the next election

\footnotetext{
${ }^{4}$ See Eslava (2011) and Kirchgässner (2013) on political economic approaches describing why politicians run fiscal deficits.

${ }^{5}$ German state governments have little discretionary power over their revenues. State governments mainly adjust their budgets on the expenditure side.

${ }^{6}$ See also Heinemann and Hennighausen (2012) and Stix (2013) on what predicts public opinion towards public debt.
} 
they may change their borrowing behavior. ${ }^{7}$ There are two theories. Alesina and Tabellini (1990) assume that incumbents increase deficit-financed expenditures on the preferred type of public goods before elections to reduce the room for maneuver of successors. Accordingly, rightwing and leftwing governments would both increase deficits before elections. Persson and Svensson (1989) assume that rightwing governments cut taxes before elections to force successors into low expenditure levels and hence run deficits. Leftwing governments increase taxes before elections to force successors into high expenditure levels and hence run surpluses. Many empirical studies do not support the theories on strategic use of deficits (Grilli et al., 1991; Crain and Tollison, 1993; Franzese, 2000; Lambertini, 2003; Brender and Drazen, 2009; Aidt and Mooney, 2014). Petterson-Lidbom (2001) finds evidence in support of the Persson and Svensson theory using data from Swedish local governments. ${ }^{8}$

Many studies on budget consolidation investigate the determinants of a successful consolidation. Consolidations are defined as successful if the debt-to-GDP ratio or the budget deficits are permanently reduced. Alesina et al. (1998) find that coalition governments are less likely to succeed in budget consolidation than single party governments. Fiscal decentralization makes successful fiscal consolidation more likely (Schaltegger and Feld 2009). Consolidation strategies differ by government ideology: leftwing governments tend to reduce the deficit by raising tax revenues while rightwing

\footnotetext{
${ }^{7}$ De Haan (2013) shows that electoral cycles are more pronounced in young democracies.

${ }^{8}$ Empirical studies have also shown that budget deficits are higher under fragmented governments (Volkerink and De Haan, 2001; Perotti and Kontopoulos, 2002). Strong budgetary institutions can, however, mitigate the effect of fragmented governments on budget deficits (De Haan et al., 2013). Strong budgetary institutions such as politically independent state supervisory authorities may also limit budget deficits that arise when local governments and state supervisory authorities belong to the same party (Roesel, 2014). Fiscal policies may also depend on fiscal decentralization. Fiscal autonomy gives rise to lower local public debt (Feld et al., 2011; Foremny, 2014). At the local level, municipalities increased debt when neighboring municipalities increased debt (Borck et al., 2015).
} 
governments rely mostly on expenditure cuts (Mulas-Granados, 2003; Tavares, 2004). Consolidations may even be more successful under leftwing governments if the commitment to budget consolidation is perceived as more credible (the "Nixon goes to China” argument, see Ross, 2000). Leftwing governments may also abstain from expansionary fiscal policies if voters are fiscal conservatives. Empirical evidence shows that voters do not reward politicians who increase public expenditure (Peltzman, 1992).

Experts examine what predicts the probability that a fiscal adjustment takes place. Mierau et al. (2007) find that upcoming elections influence the chance for a rapid fiscal adjustment to occur, whereas government ideology does not affect the probability of fiscal adjustments.

Some studies focus on governments’ fiscal policies in the German states. Jochimsen and Nuscheler (2011) use a panel dataset from 1960 to 2005. The results show that coalition governments borrowed more than single party governments and that borrowing was lower in pre-election years. Coalition governments with a finance minister of the same party as the prime minister did, however, not increase debt as compared to single party governments. Government ideology has not been shown to influence borrowing. The authors describe that electoral motives dominated the partisan effect: in a repeated game where governments offer voters' preferred platforms on election day, no government wants to deviate since it may be punished by voters at the next election. ${ }^{9}$ Jochimsen and Thomasius (2014) find that the professional background of the finance minister had a significant effect on the budget deficit in the German states between 1960 and 2009, whereas the finance minister's party affiliation had not. Public spending and

\footnotetext{
${ }^{9}$ In a similar vein, electoral motives influenced active labor market policies that promote (short term) jobcreation in the German states (Mechtel and Potrafke, 2013).
} 
deficits were higher when prime ministers of the German states had low socioeconomic backgrounds, as measured by the Standard International Occupational Prestige Scale and International Socio-Economic Index of Occupational Status (Hayo and Neumeier, 2014).

Support for the debt brake was highest among CDU voters, followed by voters of the Greens, the SPD, the FDP and Die Linke (Hayo and Neumeier, 2015a). High personal incomes, knowledge about the costs of deficit spending, and low trust in politicians’ fiscal competence gave rise to high support of fiscal consolidation (Hayo and Neumeier, 2015b). There is no study yet that empirically investigates how government ideology is related to budget consolidation in the German states after the financial crisis and after the debt brake was introduced.

\section{German Debt Brake}

A balanced-budget rule was included in the German constitution in 2009, which requires state budgets to be balanced without borrowing (Art. 109(3) GG). ${ }^{10}$ Exceptions can only be made for emergencies such as severe economic crises or natural disasters, or according to the development of the economic cycle on a symmetrical basis (Art. 109 (3) sentence 2 GG). It is unclear, however, whether there will be sanctions if a state fails to consolidate the budget until 2020 (Fuest and Thöne, 2013). The federal government established a new Stability Council consisting of the state finance ministers and the federal ministers of finance and economic affairs. The council monitors whether the federal government and the state governments pursue sustainable fiscal policies. Five highly indebted states (Berlin, Bremen, Saarland, Saxony-Anhalt and Schleswig-Holstein, see

${ }^{10}$ Berlin, Mecklenburg-Western-Pomerania and Schleswig-Holstein voted against the new debt brake in the federal council in June 2009. See Table 1. 
Table 1) have agreed on a consolidation path, are monitored on their compliance, and receive transfers to consolidate the budgets. The Stability Council evaluates the budgets based on four performance figures (structural deficit, credit financing ratio, debt level and interest-tax-ratio) which are compared to the state average. There is, however, no common concept on how to calculate the structural deficit at the state level. The Stability Council uses the deficit per capita instead (Brügelmann and Schaefer, 2013).

The federal debt brake does not make any prescriptions for the states' fiscal policies until 2019. States are autonomous in their fiscal policy, and state governments (except for the five states with consolidation assistance) can decide on whether they want to comply with the debt brake earlier and how a balanced budget is to be reached. Since state governments have little discretionary power regarding their tax revenues, states are most likely to adjust budgets by decreasing expenditures. Expenditures that are not predetermined by the federal legislation include current employment, operating expenditures, and allowances and benefits. The states may include new laws concerning the debt brake in their constitutions. For example, the states may specify rules regarding the required approval of escape clauses in parliament, the amortization plan, the legal form of the control account, and adjustments of financial transactions.

The fiscal equalization scheme redistributes revenues across states and between the federal level and the state level. The federal government and state governments are negotiating the design of the fiscal equalization scheme after 2020. Feld (2010) and Burret and Feld (2013) describe that state governments have incentives to not balance the budgets until 2019 to negotiate higher transfers from other states or the federal level. ${ }^{11}$

\footnotetext{
${ }^{11}$ See Herwartz and Theilen (2014) on what type of state government is keen to collect taxes.
} 
States can include balanced-budget rules in the constitutions (as did Bavaria, Hamburg, Hesse, Mecklenburg-Western-Pomerania, Rhineland-Palatinate, Saxony, and Schleswig-Holstein) or in their state budget code (as did Baden-Wuerttemberg, SaxonyAnhalt, Lower Saxony, Thuringia, see Table 1). The rules in the state budget code can, however, easily be circumvented (Burret and Feld, 2013). ${ }^{12}$ If state governments change the constitution to comply with the debt brake, they indicate that they seriously want to consolidate their budgets. ${ }^{13}$ Constitutional debt brakes may, however, still contain loopholes, for example by leaving out special funds and public enterprises (Ciaglia and Heinemann, 2012; Heun, 2013; Reischmann, 2014, 2015).

Experts describe how the German debt brake is designed and whether it serves its purpose. Janeba (2012) investigates a political agency problem where policy reforms such as a previously passed new budget or debt rule are implemented with a delay. The results show that a suitable debt ceiling is more effective to restrain borrowing than a budget deficit rule. Since the debt brake will only become effective in 2020, future state governments are likely to challenge the new rules before the rules become effective (Janeba, 2012). Schleswig-Holstein, Saxony-Anhalt, and Saarland, some of the states which receive consolidation assistance, have the strictest rules. The states lack fiscal discipline because German federalism provides bailout guarantees (Ciaglia and Heinemann, 2012). Mause and Groeteke (2012) conclude that the German debt brake is not a credible commitment. Whether a debt brake is effective depends on the individual de-

\footnotetext{
12 Rules in the state budget code can be changed by simple majority, whereas the constitution is more difficult to change. Bohn and Inman (1996) show that stricter budget rules gave rise to lower deficits in the US states.

${ }^{13}$ We tested whether the level of debt influences the likelihood to introduce a debt brake at the state level. Regression coefficients in probit regressions are statistically significant and indicate that more indebted states were less likely to introduce debt brakes.
} 
sign (independent political control, sanctions etc.) and on the institutional setting. If, for example, a government can expect a bailout or poor fiscal policy is not punished by the capital markets, a debt brake rule would not change a government's incentives. The German fiscal equalization scheme renders the debt brake less effective.

\section{Governments’ Rhetoric}

Policy preferences of parties can be described by politicians' words in the public debate or in party manifestos (Osterloh, 2012). Politicians reveal their attitudes towards the debt brake in the media. In Schleswig-Holstein, the leftwing government wanted to weaken the debt brake: finance minister Heinhold "budges from the debt brake" (Schleswig-Holsteinische Zeitung, June 4, 2015). In North-Rhine Westphalia, the socialdemocratic finance minister Norbert Walter-Borjans maintained that the debt brake is somewhat self-incapacitating (dapd Nachrichtenagentur, October 13, 2011). In Hesse, the member of the state parliament Janine Wissler (leftwing party Die Linke), said that the debt brake is equivalent to cuts in social welfare (Gelnhäuser Tageblatt, March 9, 2011). Saarland's Prime Minister Annegret Kramp-Karrenbauer (CDU) questioned the debt brake by stating that a positive economic environment is needed to cope with the debt brake. Her own party and the market-oriented FDP strongly criticized her view (Berliner Morgenpost, September 28, 2011).

During the plenary debate before voting on the federal debt brake in the lower house in May 2009, MPs revealed differences in attitudes towards budget consolidation across parties. ${ }^{14}$ Volker Wissing (FDP) stressed how the interest that has to be paid on the debt burden reduces the scope of action available to politicians, and that his party strongly

\footnotetext{
${ }^{14}$ See plenary minutes No. $16 / 225$.
} 
advocates an effective debt brake. Antje Tillmann (CDU) maintained that a debt brake implies intergenerational justice. By contrast, Bodo Ramelow (Die Linke) claimed that the debt brake will render some states incapable of action, and demands higher taxes instead, for instance on wealth and financial transactions. Fritz Kuhn from (Greens) criticized that the debt brake will not be effective, because state governments are autonomous in designing their budgets until the year 2019. Peer Steinbrück (SPD), the then finance minister, claimed that a signal to the financial markets is needed, that Germany pursues sound budgetary policies.

Party manifestos in individual states since 2009 also contain the party position regarding debt brakes. There were 23 state elections between 2009 and 2014, and party manifestos were published before each election. We examined whether manifestos contained crystal-clear statements in favor or against debt brakes at the state or federal level. Table 2 shows the results. Parties clearly differed in their attitudes towards debt brakes. While the conservative CDU/CSU and the market-oriented FDP advocated the debt brake in 20 and 18 out of 23 party manifestos, the leftwing SPD only advocated the debt brake in 9 party manifestos. The leftwing Green party advocated the debt brake in 15 party manifestos, and dismissed it in 3 party manifestos. The leftwing party Die Linke never advocated the debt brake and dismissed it in 13 party manifestos.

Anecdotal evidence corroborates that political parties in the public debate differed considerably in their attitudes towards debt brakes. We now examine whether the expressed differences in attitudes towards fiscal consolidation of the political parties were also reflected in the data. 


\section{Governments’' Actions}

\subsection{Voting behavior}

Political alignment mattered when the German lower house decided to introduce the debt brake at the federal level in May 2009. Political alignment also mattered for voting behavior when a bill concerning the debt brake at the state level was introduced. Table 3 shows the results of parties' roll call votes in the state parliaments. MPs of the CDU/CSU always voted in favor of the debt brake. MPs of the FDP always voted in favor of the debt brake, except for Saxony-Anhalt where they abstained from voting. In Saxony one MP of the SPD voted against the debt brake, in Lower-Saxony and Thuringia all MPs of the SPD voted against the debt brake. In the other states all MPs of the SPD voted in favor of the debt brake. In Bavaria and Lower Saxony all MPs of the Greens voted against the debt brake. In Saxony one MP of the Greens voted against the debt brake. MPs of Die Linke never supported the debt brake, except in Saxony where 11 MPs voted in favor of the debt brake.

\subsection{Policy measures}

State governments have little discretionary power designing taxes. One of the few taxes that federal states decide on and collect is the land transfer tax. Expenditures that are not predetermined by the federal legislation include current employment, operating expenditures, and allowances and benefits. The highest share of expenditures is personnel expenditures. Aggregate data on expenditure types do not capture all facets of consolidation strategies. For example, personnel expenditures can be reduced by hiring fewer teachers or fewer administrative senior government officials. It is worthwhile to examine whether government ideology influences consolidation strategies. In July 2014 we 
asked experts in the Ministries of Finance of all German states which consolidation strategies state governments pursued after the federal debt brake had been introduced. The experts work in the units dealing with issues such as the budget, federal relationships, tax revenue forecasting or fiscal planning. Table 4 portrays the results. We describe three states with particularly interesting anecdotal evidence in some more detail.

Schleswig-Holstein was the first state to include a debt brake in the state constitution in May 2010. Including a debt brake in the constitution was among the first decisions of the new rightwing government. The debt brake had been a major issue in the election campaign. In 2009, Schleswig-Holstein, still governed by a mixed coalition government, had been among the three states that voted against the debt brake at the federal level in the Federal Council. When the state parliament decided to file a suit against the debt brake, the rightwing CDU was the only party that did not support the lawsuit. Attitudes concerning the debt brake clearly differed between leftwing and rightwing governments/parties, and so do the attitudes regarding consolidation strategies. The rightwing government decided to reduce public employment between 2010 and 2020. The leftwing government which came into office in June 2012 approved the agreed deficit targets, but had different priorities on how to consolidate the budget. For example, the government wanted to cut fewer teacher positions than planned. ${ }^{15}$ Instead, more jobs in the public administration would be cut.

Saxony has the lowest debt per capita level of all states. The rightwing CDU has been in power since 1990 (over the period 2004-2009 in a coalition with the leftwing SPD). The state government ran budget surpluses since 2006. The debt brake, included

\footnotetext{
${ }^{15}$ The leftwing government wants to cut only half of the originally planned teacher positions and provide the third year of nursery school free of charge. See Frankfurter Rundschau, May 9, 2012.
} 
in the state constitution in July 2013, forbids public borrowing starting in 2014. The debt brake also includes provisions to cover implicit debt arising from pension liabilities. Public employment was forecast to be cut by $18 \%$.

North Rhine-Westphalia did not include a debt brake in its constitution or state budget code. Public employment needs, however, to be reduced to comply with the debt brake in 2020. The leftwing government froze wages of civil servants in higher service instead of cutting positions in the inner administration. The wage freeze of civil servants only in higher service was declared to be not in line with the constitution. The government of North Rhine-Westphalia will thus have to pay back a high amount of foregone payment to the civil servants. Instead of cutting expenditures, the leftwing government increased investive expenditures for schooling, child care and universities hoping for lower expenditures in the future. As a consequence, expenditures for allowances and benefits have increased strongly in North Rhine-Westphalia since 2012. It is not yet clear how North Rhine-Westphalia will finance the increasing expenditures without increasing debt. Since 2012 North Rhine-Westphalia has no concrete plans for retrenchment of personnel. Some departments are required to cut back their expenditures by $1,5 \%$ until 2016, but the most personnel intense departments are excluded from the requirement. Some journalists conjectured that the land transfer tax would increase further or a municipality solidarity surcharge would be introduced. ${ }^{16}$

\subsection{Aggregate outcomes}

When the new debt brake law was passed in 2009 public debt differed considerably between the states. States such as Bremen, Berlin, Hamburg and Saarland had high debt

\footnotetext{
${ }^{16}$ See e.g. Rheinische Post, Juli 3, 2014 and Aachener Nachrichten, September 26, 2013.
} 
per capita levels between $10,000 €$ and $24,000 €$ in 2009, whereas states such as Saxony, Bavaria and Baden-Wuerttemberg had debt per capita levels between 1,000€ and 5,000€ in 2009. Figure 1 shows the average level of debt per capita for the year 2009 by the type of government. Leftwing governments had higher debt per capita in 2009 than rightwing and mixed coalition governments. Voters in states with poor economic performance and high debt are more prone to vote for leftwing parties because they favor a large size and scope of government and high social spending. The consolidation path needed to achieve zero structural deficits by 2020 hence differs considerably between states. Simulations by Detemple et al. (2013) foreshadow, for example, that Saarland, Saxony-Anhalt and Bremen would only achieve zero structural deficits by 2020 if their spending after provisions and interest payments nominally shrank relative to the 2012 level. Mecklenburg-Western-Pomerania, Thuringia, Hesse, Brandenburg, RhinelandPalatinate, Saxony, and North Rhine-Westphalia have to cut their budgets in real terms. Berlin, Schleswig-Holstein, Hamburg and Lower Saxony can moderately increase yearly budgets in real terms. Bavaria and Baden-Wuerttemberg would even be allowed to increase their spending and could still have balanced budgets in 2020. Against the background that the population is shrinking especially in East German states, in per capita terms the budgets of Bremen and Saarland have to decrease in nominal terms. Deubel et al. (2015) describe that the Saarland, Saxony-Anhalt, Thuringia, Bremen, and Mecklenburg-Western-Pomerania still need to reduce real spending (excluding interest and state pensions) by 2020, relative to their 2014 level.

We use data on the structural budget deficit per capita as computed by the Stability Council. The data is available for the years 2010-2014. The structural deficit is obtained by netting out financial transactions from the deficit. Business-cycle fluctuations are not 
eliminated in the data, because members of the Stability Council had not yet agreed on the methodology. We also use data on the deficit per capita and the primary deficit per capita for the years 2009-2014 from the monthly reports of the Federal Ministry of Finance. The primary deficit excludes interest expenditures. ${ }^{17}$ We use debt per capita variables from the Federal Statistical Office.

Figure 2 shows three deficit measures for the German states over the time period 2009-2014. The solid line describes the structural deficit per capita, the dashed line the deficit per capita and the dotted line the primary deficit per capita. The shaded areas show the type of government in power: red describes a leftwing government; black describes a rightwing government and gray describes a mixed coalition government. There were six changes of state government ideology in the years 2010 to 2014, four changes occurred from a rightwing to a more leftwing government (Baden-Wuerttemberg, Lower Saxony, North Rhine-Westphalia and Schleswig-Holstein). In Hamburg, a leftwing government took over from a mixed coalition government in 2011, and in Berlin, a mixed coalition government took over from a leftwing government in $2011{ }^{18}$ We expect that deficits increased after a leftwing government took over from a rightwing government. In all states deficits declined over time. Negative deficits correspond to budget surpluses.

In 2014, at the end of the observation period, all states ran primary surpluses. Five states with leftwing governments (Bremen, Lower Saxony, North Rhine-Westphalia, Rhineland-Palatinate, Schleswig-Holstein), one state with a rightwing government

\footnotetext{
17 The federal states faced low interest expenditure over the period 2010-2014. Under leftwing governments the lagged debt per capita was on average $12,677 €$ compared to 5,082€ under rightwing governments. The highly indebted leftwing states hence benefit most from the low interest rates.

${ }^{18}$ In the fall 2014, elections took place in Saxony, Thuringia and Brandenburg. The new governments did not change the budgets for 2014 .
} 
(Hesse), and one state with a mixed coalition government (Saarland) still ran overall deficits.

Figure 3 shows the average deficit per capita for different types of governments. The average structural deficit per capita between 2010 and 2014 was $43 €$ under rightwing governments and $250 €$ under leftwing governments. A t-test indicates that structural deficits per capita were significantly higher under leftwing governments than under rightwing governments (significant at the $5 \%$ level). The average deficit per capita between 2009 and 2014 was $136 €$ under rightwing governments and 292€ under leftwing governments. The difference between average deficit per capita run by rightwing and leftwing governments was statistically significant at the $10 \%$ level. The relation between government ideology and primary deficits was different. The average primary deficit per capita between 2009 and 2014 was -48€ (i.e., a surplus) under rightwing governments, $-107 €$ under leftwing governments and -237€ under mixed coalition governments. The average primary balance did not differ significantly between rightwing and leftwing governments. Mixed coalition governments, however, run significantly lower primary deficits than governments of one party or of parties sharing similar ideologies.

So why did especially leftwing politicians dismiss budget consolidation in the public debate, while in fact implementing budget consolidation when they were in office?

The economic conditions were quite favorable and have helped the states to consolidate their budgets since 2010. Tax income was high and interest expenses low. Figure 4 shows the average difference between the actual tax revenues and the projected tax rev- 
enues in the last fiscal plan for a given year over the period 2009-2014. ${ }^{19}$ During the financial crisis in 2009 tax revenues were lower than expected. In the years 2010 and 2011 the states received on average large unexpected additional tax revenues. Between 2012 and 2014 expectations of the amount of tax revenues were gradually adjusted upwards, but the states still received more tax revenues than expected. ${ }^{20}$ With the additional tax income and low interest expenses, the states had an opportunity to finance their expenses without issuing too much new debt. The favorable economic conditions explain the low level of primary deficits per capita in the last years. The economic environment spared state governments - the political alignment notwithstanding - to implement rigorous consolidation programs. A reduction in deficits was possible without having to cut back benefits.

We do not estimate an econometric model because we cannot identify a causal effect of government ideology on consolidation strategies. The number of observations is not sufficient to use, for example, a regression discontinuity approach. We cannot solve the reverse causality problem by using an instrumental variable for government ideology either. Such an instrumental variable for government ideology in macro panel data models does not yet exist. Future research needs to examine whether government ideology influenced fiscal deficits. An identification strategy for a causal effect should also

\footnotetext{
${ }^{19}$ There were no projected tax revenues published for the same year in Rhineland-Palatinate (2009, 2012, 2014), Schleswig Holstein (2009), Mecklenburg-Western-Pomerania (2010, 2012, 2014), Bavaria (2011), and Bremen (2011, 2014). We instead used projections that were made the previous year in those cases.

${ }^{20}$ On political manipulation of tax revenue forecasts see, for example, Buettner and Kauder (2015) and Kauder et al. (2015).
} 
consider the initial debt-to-GDP ratio. ${ }^{21}$ New research for the German states may, of course, include data for the years that are yet to come.

\section{Conclusion}

Against the background of the new German debt brake we described to what extent government ideology influences how state governments consolidate budgets. Anecdotal evidence corroborates that political parties in the public debate differed in their attitudes towards fiscal consolidation strategies. Descriptive statistics indicate that leftwing governments ran on average higher structural deficits than rightwing governments between 2010 and 2014. The findings also suggest that government ideology influenced fiscal policies, especially consolidation strategies. Anecdotal evidence based on expert interviews affirms that parties differed in using individual policy measures to consolidate budgets.

Using data over the period 1960-2009 previous studies did not show that government ideology influenced deficits in the German states (Jochimsen and Nuscheler, 2011; Jochimsen and Thomasius, 2014). Other studies have shown evidence for ideologyinduced policies in the German states since the 1990s: rightwing governments hired more policemen than leftwing governments; rightwing governments were active in introducing tuition fees while leftwing governments abolished tuition fees; rightwing governments spent more on universities; rightwing governments promoted economic freedom (Oberndorfer and Steiner, 2007; Potrafke, 2011; Kauder and Potrafke, 2013; Tepe and Vanhuysse, 2013; Potrafke, 2013). We conjecture that also budget consolidation

${ }^{21}$ See, for example, Bohn's (1998) fiscal reaction function that describes how the debt-to-GDP-ratio predicts the primary surplus. 
was somewhat ideology-induced in the German states over the period 2010-2014 because government ideology retired to the background at the federal level and parties now employ ideology-induced policies at the state level (Potrafke, 2012). Since 2010, however, revenues of federal taxes were much higher than expected. Leftwing governments hence did not need to run deficits to design generous budgets.

Why is it that many socialdemocratic politicians dismissed the debt brake in the public discourse but did not run deficits when in office? It is conceivable that political parties used expressive rhetoric to confirm their ideological identities (Hillman, 2010). Our results are in line with Debus (2008) who describes that the SPD adopted leftist positions on economic policy issues to gratify its core voter clientele. However, when participating in government, the SPD implemented more market-oriented economic policies than originally promised before elections. In the course of the financial crisis, the SPD might have responded to shifts in public opinion and pursued more sustainable fiscal policies (Adams et al., 2004; Bräuninger, 2009). 


\section{Acknowledgements}

We would like to thank participants of the Public Choice Conference 2014 in Charleston, the IIPF Conference 2014 in Lugano, the EEA Conference 2014 in Toulouse, and two anonymous referees for their helpful comments. Lion Henrich, Sebastian Kropp, and Ha Quyen Ngo provided excellent research assistance. 


\section{References}

Adams, J., M. Clark, L. Ezrow and G. Glasgow (2004), 'Understanding Change and Stability in Party Ideologies: Do Parties Respond to Public Opinion or to Past Election Results?’ British Journal of Political Science 34, 589-610.

Aidt, T. and G. Mooney (2014), 'Voting Suffrage and the Political Budget Cycle: Evidence from the London Metropolitan Boroughs 1902-1937', Journal of Public Economics 112, 53-71.

Alesina, A. (1987), 'Macroeconomic Policy in a Two-Party System as a Repeated Game’, Quarterly Journal of Economics 102, 651-678.

Alesina, A., O. Barbiero, C. Favero, F. Giavazzi and M. Paradisi (2015), 'Austerity in 2009-2013’, NBER Working Paper 20827.

Alesina, A., R. Perotti, J. Tavares, M. Obstfeld and B. Eichengreen (1998), 'The Political Economy of Fiscal Adjustments', Brookings Papers on Economic Activity 29, 197-266.

Alesina, A. and G. Tabellini (1990), 'Voting on the Budget Deficit', American Economic Review 80, 37-49.

Bohn, H. (1998), 'The behavior of U.S. Public Debt and Deficits', Quarterly Journal of Economics 113, 949-963.

Bohn, H. and R. P. Inman (1996), 'Balanced Budget Rules and Public Deficits: Evidence from the U.S. States’, Carnegie-Rochester Conference Series on Public Policy $45,13-76$.

Borck, R., F. M. Fossen, R. Freier and T. Martin (2015), 'Race to the Debt Trap? Spatial Econometric Evidence on Debt in German Municipalities', Regional Science and Urban Economics 53, 20-37.

Bräuninger, T. (2009), 'Responsivität und strategische Adaption im Parteienwettbewerb in den deutschen Bundesländern'. In: C. Henning (ed.), Parteienwettbewerb, Wählerverhalten und Koalitionsbildung. Nomos-Verlag, Baden-Baden, 27-46.

Brender, A. and A. Drazen (2009), 'Do Leaders Affect Government Spending Priorities?’ NBER Working Paper 15368.

Brügelmann, R. and T. Schaefer (2013), 'Konsolidierungscheck 2013 - Strukturelle Defizite in den Bundesländern', IW Köln.

Buettner, T. and B. Kauder (2015), 'Political Biases Despite External Expert Participation? An Empirical Analysis of Tax Revenue Forecasts in Germany', Public Choice 164, 287-307.

Burret, H. T. and L. P. Feld (2013), 'Fiscal Institutions in Germany', Swiss Journal of Economics and Statistics 149, 249-290.

Ciaglia, S. and F. Heinemann (2012), 'Debt Rule Federalism: The Case of Germany', ZEW Discussion Papers No. 12-067.

Crain, M. W. and R. Tollison, R. (1993), 'Time Inconsistency and Fiscal Policy: Empirical Analysis of US States', Journal of Public Economics 51, 153-159. 
Debus, M. (2008), 'Unfulfilled Promises? German Social Democrats and their Policy Positions at the Federal and State Level between 1994 and 2006', Journal of Elections, Public Opinion and Parties 18, 201-224.

De Haan, J. (2013), 'Democracy, Elections and Government Budget Deficits', German Economic Review 15, 131-142.

De Haan, J., R. Jong-A-Pin and J. O. Mierau (2013), 'Do Budgetary Institutions Mitigate the Common Pool Problem? New Empirical Evidence for the EU', Public Choice 156, 423-441.

Detemple, P., Y. Michels and T. Schramm (2013), 'PwC-Länderfinanzbenchmarking 2013: Eine Untersuchung der Länder- und Kommunalfinanzen vor dem Hintergrund der Schuldenbremse.' PricewaterhouseCoopers AG Wirtschaftsprüfungsgesellschaft.

Deubel, I., J. Hamker, D. Rumpf and D. Stegarescu (2015), 'Schuldenbremse 2020: große Unterschiede beim Konsolidierungsbedarf der Länder’, Wirtschaftsdienst 95, 200-207.

Eslava, M. (2011), 'The Political Economy of Fiscal Deficits: A Survey', Journal of Economic Surveys 25, 645-673.

Feld, L. P. (2010), 'Sinnhaftigkeit und Effektivität der deutschen Schuldenbremse', Perspektiven der Wirtschaftspolitik 11, 226-245.

Feld, L. P., G. Kirchgässner and C. A. Schaltegger (2011), 'Municipal Debt in Switzerland: New Empirical Results’, Public Choice 149, 49-64.

Foremny, D. (2014), 'Sub-National Deficits in European Countries: The Impact of Fiscal Rules and Tax Autonomy', European Journal of Political Economy 34, 86110.

Franzese, R. J. (2000), 'Electoral and Partisan Manipulation of Public Debt in Developed Democracies, 1956-90’, In R. Strauch and J. von Hagen (eds.), Institutions, Politics and Fiscal Policy, Kluwer, Boston/London, 61-86.

Fuest, C. and M. Thöne (2013), 'Durchsetzung der Schuldenbremse in den Bundesländern', FiFo Köln.

Grilli, V., D. Masciandaro and G. Tabellini (1991), 'Political and Monetary Institutions and Public Finance Policies in Industrial Democracies', Economic Policy 13, 342392.

Hayo, B. and F. Neumeier (2014), 'Political Leaders' Socioeconomic Background and Fiscal Performance in Germany’, European Journal of Political Economy 34, 184205.

Hayo, B. and F. Neumeier (2015a), 'The Debt Brake in the Eyes of the German Population', International Economics and Economic Policy, forthcoming.

Hayo, B. and F. Neumeier (2015b), 'Public Attitudes Toward Fiscal Consolidation: Evidence from a Representative German Population Survey’, Kyklos, forthcoming.

Heinemann, F. and T. Hennighausen (2012), 'Understanding Public Debt Preferences', FinanzArchiv 68, 406-430. 
Herwartz, H. and B. Theilen (2014), 'On the Political and Fiscal Determinants of Income Redistribution under Federalism and Democracy: Evidence from Germany’, Public Choice 159, 121-139.

Heun, W. (2013), 'Balanced Budget Requirements and Debt Brakes Feasibility and Enforcement', German Economic Review 15, 100-115.

Hibbs, D. A. Jr. (1977), 'Political Parties and Macroeconomic Policy', American Political Science Review 71, 1467-1487.

Hillman, A. L. (2010), 'Expressive Behavior in Economics and Politics', European Journal of Political Economy 26, 403-418.

Janeba, E. (2012), 'Germany's New Debt Brake: A Blueprint for Europe?’ FinanzArchiv 68, 383-405.

Jochimsen, B. and R. Nuscheler (2011), 'The Political Economy of the German Lander Deficits: Weak Governments Meet Strong Finance Ministers', Applied Economics 43, 2399-2415.

Jochimsen, B. and S. Thomasius (2014), 'The Perfect Finance Minister: Whom to Appoint as Finance Minister to Balance the Budget', European Journal of Political Economy 34, 390-408.

Kauder, B. and N. Potrafke (2013), 'Government Ideology and Tuition Fee Policy: Evidence from the German States', CESifo Economic Studies 59, 628-649.

Kauder, B., N. Potrafke and C. Schinke (2015), 'Manipulating Fiscal Forecasts: Evidence from the German States', Mimeo.

Kirchgässner, G. (2013), 'On the Political Economy of Public Deficits and Debt', German Economic Review 15, 116-130.

Lambertini, L. (2003), 'Are Budget Deficits Used Strategically?’ Boston College Working Papers in Economics No. 578.

Mause, K. and F. Groeteke (2012), 'New Constitutional “Debt Brakes” for Euroland? A Question of Institutional Complementarity’, Constitutional Political Economy 23, 279-301.

Mechtel, M. and N. Potrafke (2013), 'Electoral Cycles in Active Labor Market Policies', Public Choice 156, 181-194.

Mierau, J. O., R. Jong-A-Pin and J. de Haan (2007), 'Do Political Variables Affect Fiscal Policy Adjustment Decisions? New Empirical Evidence’, Public Choice 133, 297-319.

Mulas-Granados, C. (2003), 'The Political and Economic Determinants of Budgetary Consolidation in Europe', European Political Economy Review 1, 15- 39.

Oberndorfer, U. and V. Steiner (2007), 'Generationen- oder Parteienkonflikt? Eine empirische Analyse der deutschen Hochschulausgaben’, Perspektiven der Wirtschaftspolitik 8, 165-183.

Osterloh, S. (2012), 'Words Speak Louder than Actions: The Impact of Politics on Economic Performance', Journal of Comparative Economics 40, 318-336. 
Peltzman, S. (1992), 'Voters as Fiscal Conservatives', Quarterly Journal of Economics 107, 327-361.

Perotti, R. and Y. Kontopoulos (2002), 'Fragmented Fiscal Policy' Journal of Public Economics 86, 191-222.

Petterson-Lidbom, P. (2001), 'An Empirical Investigation of the Strategic Use of Debt', Journal of Political Economy 109, 570-583.

Persson, T. and L. E. O. Svensson (1989), 'Why a Stubborn Conservative Would Run a Deficit: Policy with Time-Inconsistent Preferences', Quarterly Journal of Economics 104, 325-345.

Potrafke, N. (2011), 'Public Expenditures on Education and Cultural Affairs in the West German States: Does Government Ideology Influence the Budget Composition?' German Economic Review 12, 124-145.

Potrafke, N. (2012), 'Is German Domestic Social Policy Politically Controversial?' Public Choice 153, 393-418.

Potrafke, N. (2013), 'Economic Freedom and Government Ideology across the German States', Regional Studies 47, 433-449.

Potrafke, N. and M. Reischmann (2015), 'Fiscal Transfers and Fiscal Sustainability', Journal of Money, Credit and Banking 47, 975-1005.

Reischmann, M. (2014), 'Staatsverschuldung in Extrahaushalten: Historischer Überblick und Implikationen für die Schuldenbremse in Deutschland', Perspektiven der Wirtschaftspolitik 15, 171-181.

Reischmann, M. (2015), 'Creative Accounting and Electoral Motives: Evidence from OECD Countries', Journal of Comparative Economics, forthcoming.

Roesel, F. (2014), 'Co-Partisan Buddies or Partisan Bullies? Why State Supervision of Local Government Borrowing Fails’, ifo Working Paper 189.

Ross, F. (2000), 'Beyond Left and Right: The New Partisan Politics of Welfare', Governance 13, 155-183.

Schaltegger, C. A. and L. P. Feld (2009), 'Are Fiscal Adjustments Less Successful in Decentralized Governments?’ European Journal of Political Economy 25, 115123.

Stix, H. (2013), 'Does the Broad Public Want to Consolidate Public Debt? - The Role of Fairness and of Policy Credibility’, Kyklos 66, 102-129.

Tavares, J. (2004), 'Does Right or Left Matter? Cabinets, Credibility and Fiscal Adjustments', Journal of Public Economics 88, 2447-2468.

Tepe, M. and P. Vanhuysse (2013), 'Cops for Hire? The Political Economy of Police Employment in the German States', Journal of Public Policy 33, 165-199.

Volkerink, B. and J. de Haan, J. (2001), 'Fragmented Government Effects on Fiscal Policy: New Evidence', Public Choice 109, 221-242. 


\section{Appendix}

Figure 1: Debt per capita level in 2009

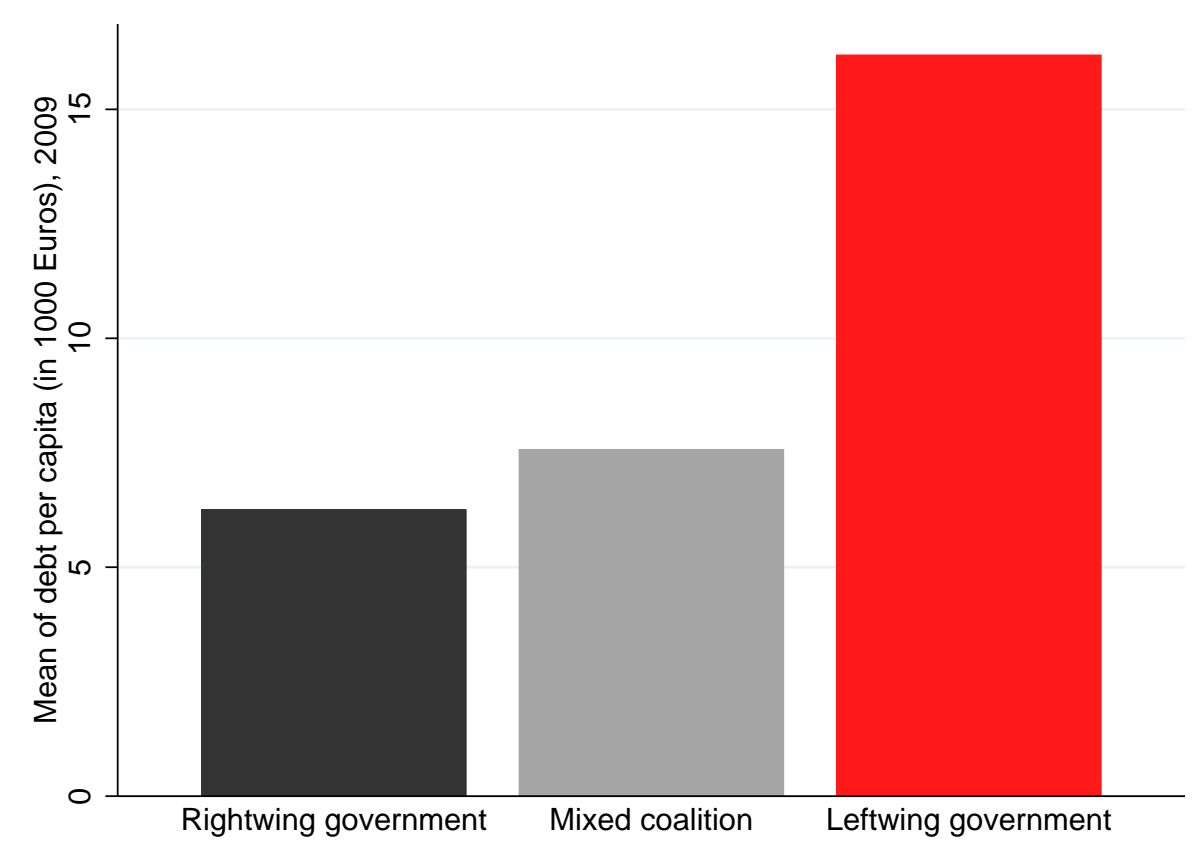

Source: Federal Statistical office, own calculations. 
Figure 2: Fiscal deficits per capita (structural, primary, and overall, in €) by states 2009-2014

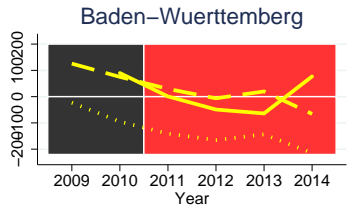

Bremen

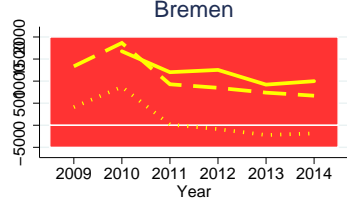

Lower Saxony

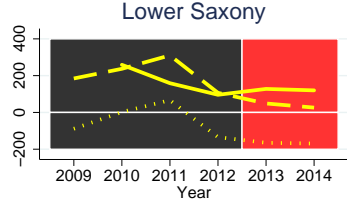

Saxony
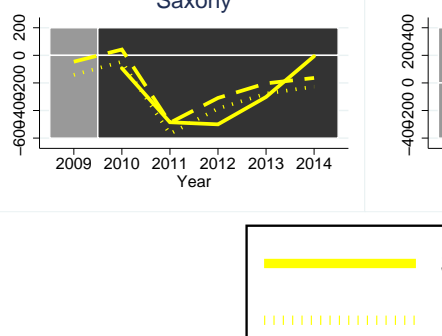

Structural deficit per capita

Primary deficit per capita

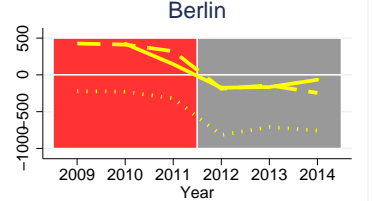

Hesse

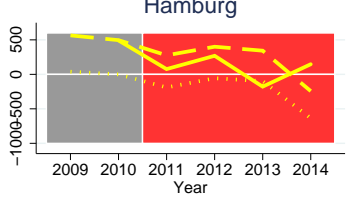

North Rhine-Westphalia

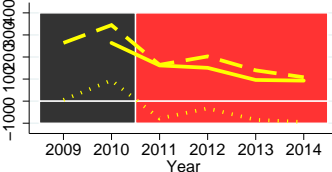

Saxony-Anhalt

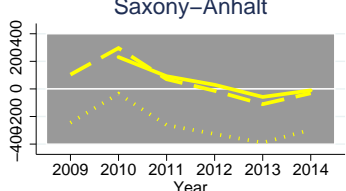

$2002010201120^{\prime} 1220132014$

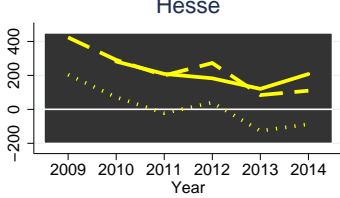

Rhineland-Palatinate

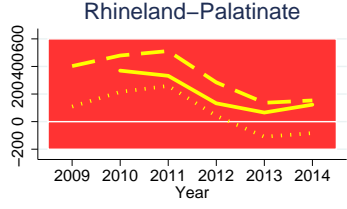

Schleswig-Holstein

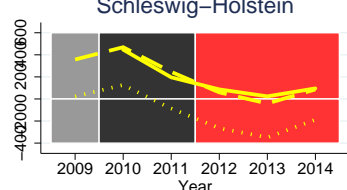

Brandenburg

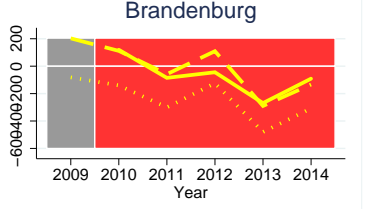

Mecklenburg-Western Pomerania

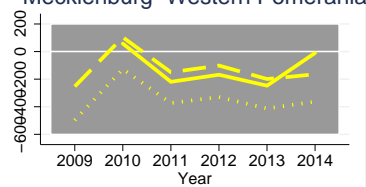

Saarland

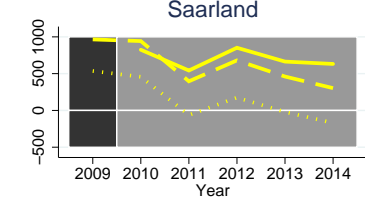

Thuringia

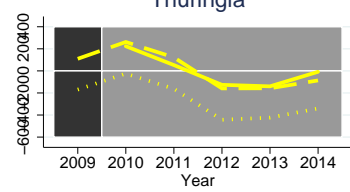

Deficit per capita

$$
\text { . }
$$

Sources: Stability Council and Monthly Reports of the Federal Ministry of Finance, own calculations. 
Figure 3: Average deficit per capita and government ideology (2009/10-2014)

(i) structural deficit

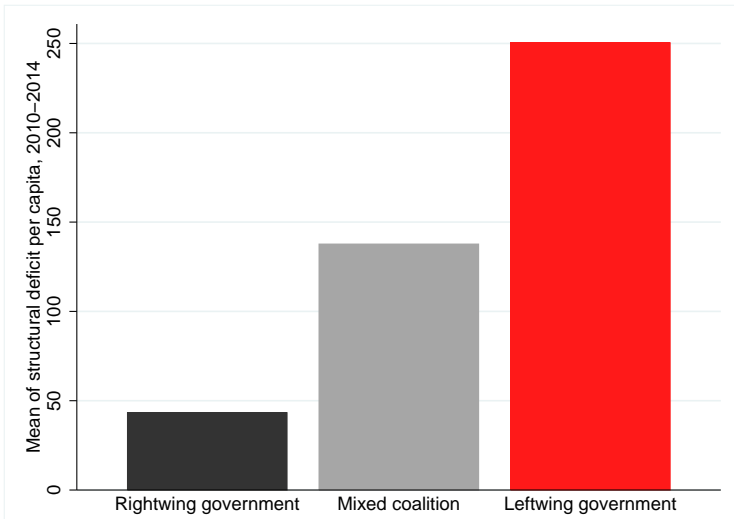

(ii) deficit

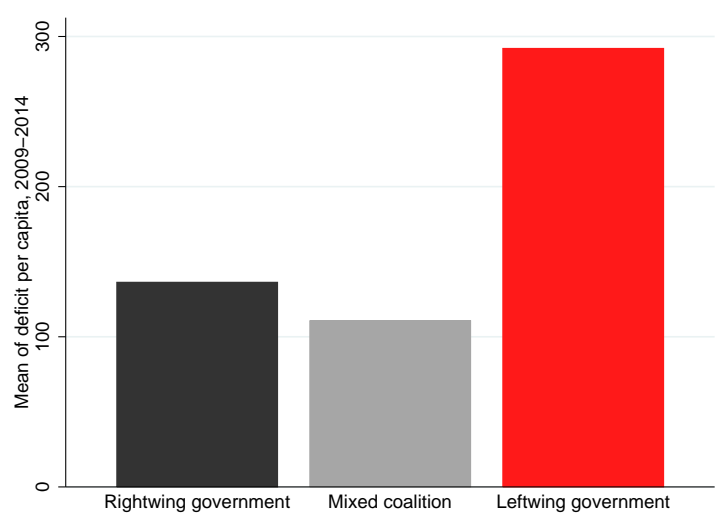

(iii) primary deficit

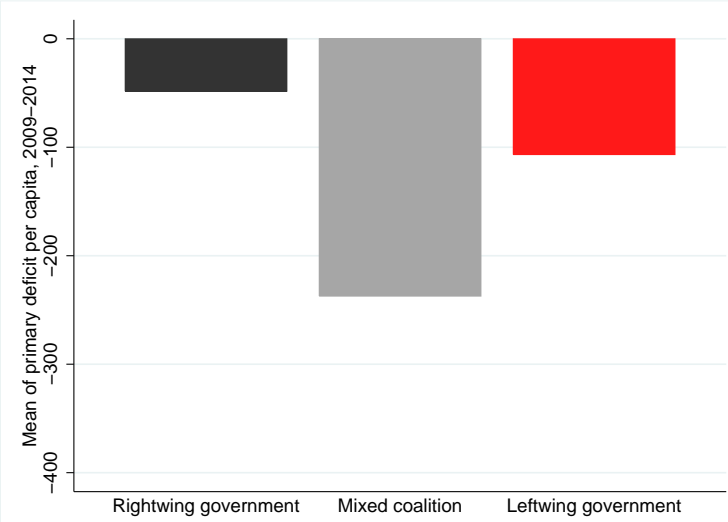

Sources: Stability Council and Monthly Reports of the Federal Ministry of Finance, own calculations. 


\section{Figure 4: Unexpected additional tax income (State average, in 1000€)}

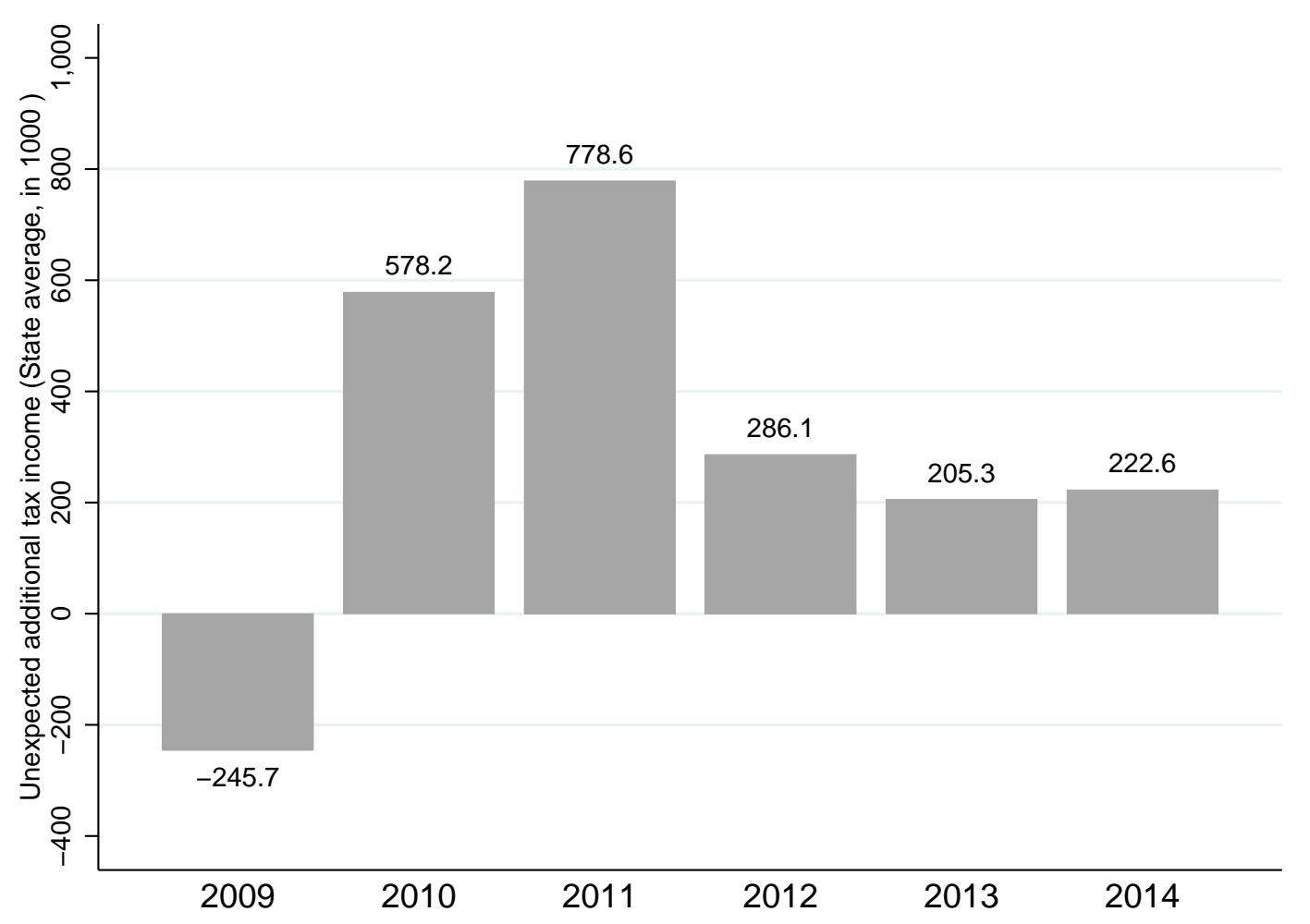

Description: The graph describes the average difference between the actual tax revenues and the projected tax revenues in the last fiscal plan for a given year. Sources: "Mittelfristige Finanzplanung der Länder", Monthly Report of the Federal Ministry of Finance, February 2015. 
Table 1: Debt brake law in the German states

\begin{tabular}{|c|c|c|c|c|c|c|}
\hline State & $\begin{array}{l}\text { Voting decision on } \\
\text { federal debt brake } \\
\text { in federal council } \\
\text { (June 12, 2009) }\end{array}$ & $\begin{array}{l}\text { Means of state } \\
\text { debt brake } \\
\text { implementation }\end{array}$ & $\begin{array}{l}\text { Date of parliamen- } \\
\text { tary vote }\end{array}$ & $\begin{array}{l}\text { Government ideol- } \\
\text { ogy at parliamen- } \\
\text { tary vote }\end{array}$ & $\begin{array}{l}\text { Date of popular } \\
\text { vote on change of } \\
\text { constitution }\end{array}$ & $\begin{array}{l}\text { Receives con- } \\
\text { solidation } \\
\text { assistance }\end{array}$ \\
\hline Baden-Wuerttemberg & Yes & $\begin{array}{l}\text { state budget } \\
\text { code }\end{array}$ & December 2012 & Leftwing & - & - \\
\hline Berlin & No & - & - & & - & Yes \\
\hline Brandenburg & Yes & - & - & & - & - \\
\hline Bremen & Yes & Constitution & January 2015 & Leftwing & - & Yes \\
\hline Hamburg & Yes & Constitution & June 2012 & Leftwing & No & - \\
\hline Hesse & Yes & Constitution & December 2010 & Rightwing & March 2011 & - \\
\hline $\begin{array}{l}\text { Mecklenburg-Western- } \\
\text { Pomerania }\end{array}$ & No & Constitution & June 2011 & Mixed Coalition & No & - \\
\hline Lower Saxony & Yes & $\begin{array}{l}\text { state budget } \\
\text { code }\end{array}$ & September 2012 & Rightwing & - & - \\
\hline North Rhine-Westphalia & Yes & - & - & & - & - \\
\hline Rhineland-Palatinate & Yes & Constitution & December 2010 & Leftwing & No & - \\
\hline Saarland & Yes & - & - & & - & Yes \\
\hline Saxony & Yes & Constitution & July 2013 & Rightwing & No & - \\
\hline Saxony-Anhalt & Yes & $\begin{array}{l}\text { state budget } \\
\text { code }\end{array}$ & November 2010 & Mixed Coalition & - & Yes \\
\hline Schleswig-Holstein & No & Constitution & May 2010 & Rightwing & No & Yes \\
\hline
\end{tabular}




\begin{tabular}{lllll}
\hline Thuringia & Yes & state budget & July 2009 & Rightwing \\
& & code & \\
\hline Source: Own collection. & &
\end{tabular}

Source: Own collection. 
Table 2: Attitudes towards debt brake in individual party manifestos (years 2009 - 2014)

\begin{tabular}{llllll}
\hline & CDU/CSU & SPD & FDP & Greens & Die Linke \\
\hline Attitudes towards the debt brake & & & & & \\
Number of party manifestos with positive attitude & 20 & 9 & 18 & 15 & 0 \\
\hline Number of party manifestos with negative attitude & 0 & 0 & 0 & 2 & 13 \\
\hline Total number of party manifestos & 23 & 23 & 23 & 23 & 23 \\
\hline
\end{tabular}

Total number of party manifestos

Note: Only clear statements are recorded. Consequently the sum of negative and positive statements does not

necessarily correspond to the total number of investigated party manifestos.

Source: Own collection based on party manifestos. 
Table 3: Voting behavior of individual parties

\begin{tabular}{|c|c|c|c|c|c|c|}
\hline $\begin{array}{c}\text { Parliament (Federal/State Le- } \\
\text { vel) }\end{array}$ & Draft proposed by & CDU & SPD & FDP & The Greens & Die Linke \\
\hline Germany (Bundestag) & CDU/CSU, SPD & $\begin{array}{c}1 \text { no / rest } \\
\text { yes }\end{array}$ & $\begin{array}{l}19 \text { no / rest } \\
\text { yes }\end{array}$ & $\begin{array}{c}1 \text { yes / } 3 \text { no / rest abstai- } \\
\text { ned }\end{array}$ & $\begin{array}{c}1 \text { abstained / rest } \\
\text { no }\end{array}$ & no \\
\hline Bavaria & $\begin{array}{l}\text { various MPs from } \\
\text { CSU, SPD, FDP and FW }\end{array}$ & yes & yes & yes / 1 abstained & no / 1 abstained & - \\
\hline Bremen & $\begin{array}{l}\text { CDU } \\
\text { SPD, Greens }\end{array}$ & yes & yes & yes & yes & no \\
\hline Hesse & CDU, FDP & yes & yes & yes & yes & no \\
\hline $\begin{array}{l}\text { Mecklenburg-Western- } \\
\text { Pomerania }\end{array}$ & CDU, SPD & yes & yes & yes & - & no \\
\hline Lower Saxony & $\begin{array}{l}\text { CDU, FDP } \\
\text { (Draft law to change state } \\
\text { budget code) }\end{array}$ & yes & no & yes & no & no \\
\hline Rhineland-Palatinate & CDU, SPD, FDP & yes & yes & yes & - & - \\
\hline Saxony & CDU, SPD, FDP, Greens & yes & 1 no / rest yes & yes & 1 no / rest yes & $\begin{array}{c}11 \text { yes / } 11 \text { no / } 5 \text { abstai- } \\
\text { ned }\end{array}$ \\
\hline Saxony-Anhalt & $\begin{array}{l}\text { state government } \\
\text { (Draft law to change state } \\
\text { budget code) }\end{array}$ & yes & yes & abstained & - & no \\
\hline Schleswig-Holstein & $\begin{array}{l}\text { CDU, SPD, FDP, Greens, } \\
\text { SSW }\end{array}$ & yes & yes & yes & yes & no \\
\hline Thuringia & $\begin{array}{l}\text { state government } \\
\text { (Draft law to change state } \\
\text { budget code) }\end{array}$ & yes & no & - & - & no \\
\hline
\end{tabular}

Note: Exact voting behavior in Baden-Wuerttemberg and Hamburg is unknown (no recorded roll call vote). Source: minutes of parliamentary meetings. 
Table 4: Consolidation Strategies

\begin{tabular}{|c|c|c|c|c|c|}
\hline State & $\begin{array}{l}\text { Structural } \\
\text { deficit** } \\
\text { per capita } \\
2014 \text { (in } € \text { ) }\end{array}$ & Government ideology & $\begin{array}{l}\text { Planned } \\
\text { achievement } \\
\text { of (structur- } \\
\text { al) zero- } \\
\text { deficit target }\end{array}$ & $\begin{array}{l}\text { Expenditure cutting measures (esp. } \\
\text { personnel expenditure) }\end{array}$ & $\begin{array}{l}\text { Revenue enhancing measures } \\
\text { (esp. land transfer tax) }\end{array}$ \\
\hline $\begin{array}{l}\text { Baden- } \\
\text { Wuerttemberg }\end{array}$ & 77 & $\begin{array}{l}\text { 2008-2010: Rightwing } \\
\text { 2011-2014: Leftwing }\end{array}$ & 2016 & $\begin{array}{l}\text { Reducing public employment, including } \\
\text { teachers, but less than originally planned }\end{array}$ & $\begin{array}{l}\text { Increase land transfer tax from } \\
3.5 \% \text { to } 5 \%(5.11 .2011)\end{array}$ \\
\hline Bavaria & 58 & 2008-2014: Rightwing & 2015 & $\begin{array}{l}\text { Reducing public employment (cutting } 384 \\
\text { jobs between } 2014 \text { and 2016) while in- } \\
\text { creasing employment in tax administra- } \\
\text { tion, security and education, limited wage } \\
\text { increases }\end{array}$ & No increase \\
\hline Berlin* & -66 & $\begin{array}{l}\text { 2008-2010: Leftwing } \\
\text { 2011-2014: Mixed } \\
\text { coalition }\end{array}$ & 2015 & $\begin{array}{l}\text { Reducing employment in public admin- } \\
\text { istration by } 2.7 \% \text { between } 2013 \text { and } 2016\end{array}$ & $\begin{array}{l}\text { Increase land transfer tax from } \\
4.5 \% \text { to } 5 \%(1.4 .2012) \text {, from } 5 \% \\
\text { to } 6 \%(1.1 .2014) \text {, additional } \\
\text { accommodation tax since } 2014\end{array}$ \\
\hline Brandenburg & -91 & $\begin{array}{l}\text { 2008-2009: Mixed } \\
\text { coalition } \\
\text { 2010-2014: Leftwing }\end{array}$ & $\begin{array}{l}\text { already } \\
\text { achieved }\end{array}$ & $\begin{array}{l}\text { Overall expenditures forecast to decrease } \\
\text { by } 1.8 \% \text { between } 2012 \text { and 2016, cutting } \\
20,000 \text { jobs until } 2016 \text {. }\end{array}$ & $\begin{array}{l}\text { Increase land transfer tax from } \\
3.5 \% \text { to } 5 \%(1.1 .2011)\end{array}$ \\
\hline Hamburg & 147 & $\begin{array}{l}\text { 2008-2010: Mixed } \\
\text { coalition } \\
\text { 2011-2014: Leftwing }\end{array}$ & 2019 & $\begin{array}{l}\text { Planned reduction of public employment, } \\
\text { but effectively public employment in- } \\
\text { creased }\end{array}$ & $\begin{array}{l}\text { Increase land transfer tax from } \\
3.5 \% \text { to } 4.5 \%(1.1 .2009)\end{array}$ \\
\hline Hesse & 208 & 2008-2014: Rightwing & 2017 & $\begin{array}{l}\text { Reducing public employment in admin- } \\
\text { istration, not teachers }\end{array}$ & $\begin{array}{l}\text { Increase land transfer tax from } \\
3.5 \% \text { to } 5 \%(1.1 .2013) \text {, from } 5 \% \\
\text { to } 6 \%(1.8 .2014)\end{array}$ \\
\hline $\begin{array}{l}\text { Mecklenburg- } \\
\text { Western-Pomerania }\end{array}$ & -10 & $\begin{array}{l}\text { 2008-2014: Mixed } \\
\text { coalition }\end{array}$ & $\begin{array}{l}\text { already } \\
\text { achieved }\end{array}$ & $\begin{array}{l}\text { Reducing public employment by 20\% } \\
\text { between } 2003 \text { and } 2013\end{array}$ & $\begin{array}{l}\text { Increase land transfer tax from } \\
3.5 \% \text { to } 5 \%(1.7 .2012)\end{array}$ \\
\hline Lower Saxony & 120 & 2008-2012: Rightwing & Rightwing & Programs to cut administration substantial- & Increase land transfer tax from \\
\hline
\end{tabular}




\begin{tabular}{|c|c|c|c|c|c|}
\hline & & 2013-2014: Leftwing & $\begin{array}{l}\text { government: } \\
2017 \\
\text { Leftwing } \\
\text { government: } \\
2020\end{array}$ & $\begin{array}{l}\text { ly, more hesitant with cutting teacher } \\
\text { positions, but reductions are planned }\end{array}$ & $\begin{array}{l}3.5 \% \text { to } 4.5 \%(1.1 .2011), \text { from } \\
4.5 \% \text { to } 5 \%(1.1 .2014)\end{array}$ \\
\hline $\begin{array}{l}\text { North Rhine- } \\
\text { Westphalia }\end{array}$ & 93 & $\begin{array}{l}\text { 2008-2009: Rightwing } \\
\text { 2010-2014: Leftwing }\end{array}$ & after 2017 & $\begin{array}{l}\text { No clear concept of personnel expenditure } \\
\text { cuts, some departments are required to cut } \\
\text { back their expenditures by } 1,5 \% \text { until } \\
\text { 2016, but the most personnel intense de- } \\
\text { partments are excluded, unconstitutional } \\
\text { wage freeze of civil servants in higher } \\
\text { service }\end{array}$ & $\begin{array}{l}\text { Increase land transfer tax from } \\
3.5 \% \text { to } 5 \%(1.10 .2011)\end{array}$ \\
\hline Rhineland-Palatinate & 123 & 2008-2014: Leftwing & after 2017 & $\begin{array}{l}\text { Reducing public employment, being con- } \\
\text { servative with teachers until } 2016\end{array}$ & $\begin{array}{l}\text { Increase land transfer tax from } \\
3.5 \% \text { to } 5 \%(1.3 .2012)\end{array}$ \\
\hline Saarland* & 632 & $\begin{array}{l}\text { 2008-2009: Rightwing } \\
\text { 2010-2014: Mixed } \\
\text { Coalition }\end{array}$ & after 2017 & $\begin{array}{l}\text { Reducing employment in public admin- } \\
\text { istration, education sector excluded }\end{array}$ & $\begin{array}{l}\text { Increase land transfer tax from } \\
3.5 \% \text { to } 4.5 \%(1.1 .2012) \text {, from } \\
4.5 \% \text { to } 5.5 \%(1.1 .2013)\end{array}$ \\
\hline Saxony & -6 & $\begin{array}{l}\text { 2008-2009: Mixed } \\
\text { Coalition } \\
\text { 2010-2013: Rightwing } \\
\text { 2014: Mixed Coalition }\end{array}$ & $\begin{array}{l}\text { already } \\
\text { achieved }\end{array}$ & $\begin{array}{l}\text { Public employment is forecast to be cut by } \\
18 \%\end{array}$ & No increase \\
\hline Saxony-Anhalt* & -10 & $\begin{array}{l}\text { 2008-2014: Mixed } \\
\text { Coalition }\end{array}$ & $\begin{array}{l}\text { already } \\
\text { achieved }\end{array}$ & $\begin{array}{l}\text { Reducing employment in public admin- } \\
\text { istration }\end{array}$ & $\begin{array}{l}\text { Increase land transfer tax from } \\
3.5 \% \text { to } 5 \%(1.3 .2012)\end{array}$ \\
\hline Schleswig-Holstein* & 96 & $\begin{array}{l}\text { 2008-2009: Mixed } \\
\text { Coalition } \\
\text { 2010-2011: Rightwing } \\
\text { 2012-2014: Leftwing }\end{array}$ & 2016 & $\begin{array}{l}\text { Reduce public employment by } 10 \% \text { until } \\
2020 \text {, administration and teachers, left- } \\
\text { wing government wants to cut only half of } \\
\text { the originally planned teacher positions } \\
\text { and provide the third nursery school year } \\
\text { free of charge }\end{array}$ & $\begin{array}{l}\text { Increase land transfer tax from } \\
3.5 \% \text { to } 5 \%(1.1 .2012) \text {, from } 5 \% \\
\text { to } 6.5 \%(1.1 .2014)\end{array}$ \\
\hline Thuringia & -8 & $\begin{array}{l}\text { 2008-2009: Rightwing } \\
\text { 2010-2013: Mixed } \\
\text { Coalition } \\
\text { 2014: Leftwing }\end{array}$ & $\begin{array}{l}\text { already } \\
\text { achieved }\end{array}$ & $\begin{array}{l}\text { Reducing employment in public admin- } \\
\text { istration }\end{array}$ & $\begin{array}{l}\text { Increase land transfer tax from } \\
3.5 \% \text { to } 5 \%(7.4 .2011)\end{array}$ \\
\hline
\end{tabular}

* State receives consolidation assistance and has an austerity program which is monitored by the Stability Council until 2016.

** A negative deficit describes a surplus.

Sources: Stability Council, Fiscal Planning Reports, own collection based on personal interviews and newspaper articles. 